\title{
Quantification of Vibrio penaeicida, the etiological agent of Syndrome 93 in New Caledonian shrimp, by real-time PCR using SYBR Green I chemistry
}

\author{
Cyrille Goarant ${ }^{\underline{a}}$ and Fabrice Merien $\underline{\underline{b}}$,
}

\author{
aFREMER, Département Aquaculture en Nouvelle-Calédonie, BP 2059, 98846 Nouméa Cedex, Nouvelle- \\ Calédonie \\ ${ }^{b}$ Laboratoire de Recherche en Bactériologie, Institut Pasteur de Nouvelle-Calédonie, BP 61, 98845 Nouméa \\ Cedex, Nouvelle-Calédonie
}

Corresponding author : fmerien@pasteur.nc

\begin{abstract}
:
Shrimp farming is a small but growing industry in New Caledonia. Since 1993, "Syndrome 93" has been affecting New Caledonian shrimp farming industry every cold season, causing severe epizootic mortalities in grow-out ponds and significant losses. Highly pathogenic strains of Vibrio penaeicida are considered the etiological agent of the disease in Litopenaeus stylirostris. On one hand, studies demonstrated that healthy shrimp may carry $V$. penaeicida for weeks with a high overall prevalence, regardless of any seasonal pattern or temperature conditions. On the other hand, larvae are free of $V$. penaeicida and are also resistant to experimental infection. $V$. penaeicida is frequently detected in incoming water pumped from the bays, which was shown, by a molecular typing study, to be the infectious source. This particular epidemiological pattern highlights the major role of the factors that trigger and aggravate the disease in grow-out ponds, where shrimp populations carry the pathogen all year round. In order to gain a better understanding of "Syndrome 93" epidemiology, quantification of $V$. penaeicida both in shrimp and the shrimp farm ecosystem is necessary. This article describes the steps in the successful development of a real-time PCR quantification assay of $V$. penaeicida in shrimp haemolymph, seawater (from ponds or bays) and sediment pore water, including the choice of an accurate extraction technique. The entire detection method; including sample processing, DNA extraction and real-time PCR amplification, can be completed within $4 \mathrm{~h}$
\end{abstract}

Keywords: Extraction techniques; Mariculture; Quantification; Real-time PCR; Vibrio; Vibriosis 
Vibrio species are widely distributed in mariculture facilities throughout the world.

Vibriosis is a major disease problem in almost all farmed marine animals, including penaeid shrimp (Lightner and Lewis, 1975; Takahashi et al., 1985; Lightner, 1988; Brock and Lea Master, 1992; Mohney and Lightner, 1994). Our knowledge of the physiopathology of vibriosis in shrimp remains very limited. Indeed, very little knowledge

54 has been gained on this pathology and little is known concerning virulence factors in Vibrio spp that are pathogenic to farmed marine invertebrates. As an alternative to conventional zootechnical practices, sanitation measures could be conceivable to minimize the introduction of pathogenic Vibrio in a non-infected shrimp rearing ecosystem. Still, to meet this objective a rapid, reliable, quantitative and sensitive method for detection of this pathogen would be essential.

New Caledonia is located in the South Pacific between latitudes $19^{\circ} \mathrm{S}$ and $23^{\circ} \mathrm{S}$ and has a tropical oceanic climate. Its shrimp industry benefits from an almost virus-free status,

62 IHHNV being the only significant virus present, and its domestic stock of Litopenaeus 63 stylirostris being resistant to it (Weppe et al., 1992). From 1993, shrimp growers have had 64 to face a seasonal vibriosis named Syndrome 93 (Goarant et al., 1996 ; Mermoud et al.,

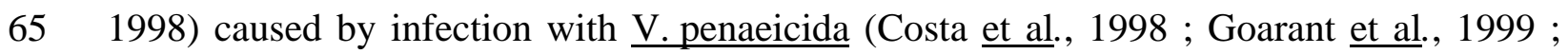

66 Saulnier et al., 2000). Therefore, the shrimp farmers' association considers the research on

67 vibriosis as the main priority. As a response, the Aquaculture Department of IFREMER

68 (French Institute for Marine Sciences) has developed a specific research program, named 69 DeSanS (possibly translated by Stylirostris Health Challenge). This research program is based on a multi-disciplinary approach; comprising of rearing technology, pond ecosystem studies, shrimp ecophysiology and immunology, nutrition, pathology and genetics. It aims 
at gaining a global explanation scheme of the seasonal vibriosis (Harache and Herbland,

73 2004) as a contribution to strengthen the sustainability of New Caledonian aquaculture.

histology and culture. Reference diagnosis includes culture and isolation of the bacteria

from the shrimp haemolymph, by using suitable media and subsequent identification.

These methods are time-consuming and require several days to obtain confirmatory results.

Additionally, lack of culturability has been frequently described in $\underline{\text { Vibrios }}$ (Huq and

Colwell, 1995; Fischer-Le-Saux et al., 2002), and in some cases these viable but nonculturable cells demonstrated to still remain infectious (Rosenberg and Ben-Haim, 2002; Baffone et al., 2003). Conventional polymerase chain reaction (PCR) method had the potential to make a dramatic impact in diagnosing infectious diseases. Using

83 Arbitrarily Primed PCR, a previous study performed in New Caledonia with local $\underline{\mathrm{V}}$. 84 penaeicida isolates demonstrated that $\underline{\mathrm{V} \text {. penaeicida }}$ was introduced in the ponds with the renewal seawater pumped from the bays (Goarant et al., 1999). Using PCR detection of

86 V. penaeicida (Saulnier et al., 2000), a wide epidemiological survey carried out over more

87 than one year confirmed these findings and demonstrated that healthy carriers were found

88 all year round in grow-out ponds (Goarant et al., 2004). This study evidenced the importance of triggering factors that turn covert infection into septicaemia. However, this PCR approach requires analysis of amplified DNA in an agarose gel, which again is time-

91 consuming and a potential source of carry-over contamination. Additionally, this study did 92 not allow accurate quantification of infection levels in shrimp or concentrations of

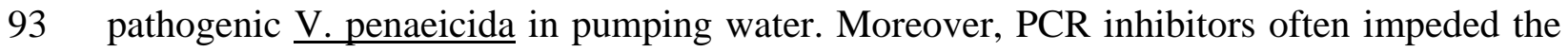

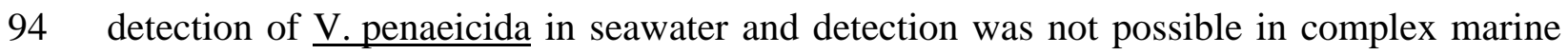

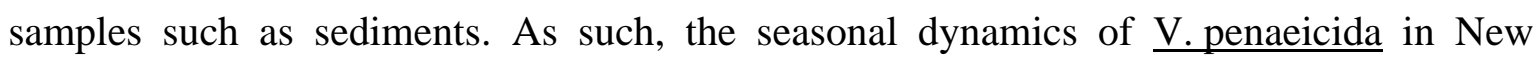

96 Caledonia remain unknown; underlying the need for an accurate tool allowing the 


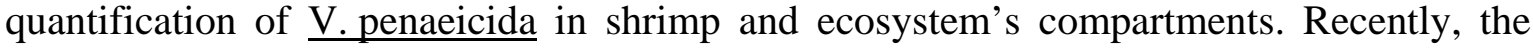
introduction of real-time PCR amplification methods using SYBR Green I as the detection technology, has made detection of bacterial pathogens such as $\underline{\text { Vibrio parahaemolyticus }}$ (Blackstone, 2003) and Vibrio vulnificus (Panicker, 2004) rapid and cost-effective.

The detection of microbial nucleic acid for the diagnosis of infection is dependent on the successful separation of nucleic acid from material (Read, 2001). In the present study we describe optimization of a real-time PCR assay using the SYBR Green I technology for rapid and sensitive detection and quantification of $\underline{\mathrm{V} \text {.penaeicida in }}$ biological (shrimp) and environmental (seawater and sediment pore water) samples. Such quantitative information obtained with our real-time PCR assay is important to obtain

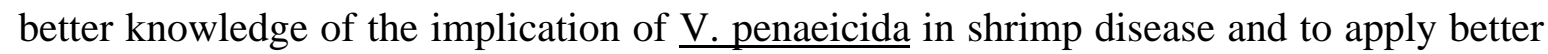
zootechnical practices. Oligonucleotide primers (Saulnier et al., 2000) targeted a segment of the $\underline{\text { rrs }}$ gene. Various nucleic acids extraction methods were used and compared, including the classic technique of phenol chloroform separation, the release of nucleic acid augmented by digestion with proteinases, and the non-specific adsorption to a matrix of silica particles held within a disposable plastic column.

\section{MATERIALS AND METHODS}

Bacterial strains. AM101 strain was isolated in 1995 from a haemoculture of a moribund shrimp suffering Syndrome 93 and was used as the reference New Caledonian

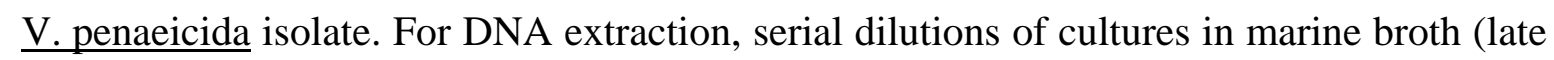
exponential phase) were plated in triplicates on Marine Agar 2216E (Difco Laboratories, Detroit, Mich.) allowing estimation of bacterial density. Pure cultures or 10-fold serial dilutions were then used. Suspensions were centrifuged at $15,000 \mathrm{x} g$ for 15 minutes at $4^{\circ} \mathrm{C}$ and the pellets were washed twice with PBS (final volume up to $200 \mu \mathrm{l}$ ). To assess the 
123 specificity of our real-time assay, we used strains from other Vibrio species ( $\underline{\text { V. penaeicida }}$

$124 \mathrm{KH}-1^{\mathrm{T}}, \underline{\mathrm{V} \text {. alginolyticus, }} \underline{\mathrm{V} \text {. harveyi, }} \underline{\mathrm{V} \text {. nigripulchritudo, }} \underline{\mathrm{V} \text {. aesturianus, }} \underline{\mathrm{V} \text {. tubiashii, }}$

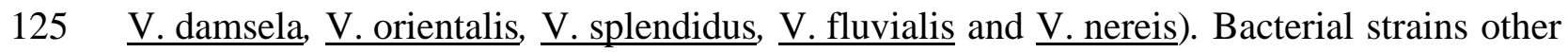

126 than members of the genus Vibrio (Proteus mirabilis, Klebsiella pneumoniae, Escherichia

127 coli, Staphylococcus aureus, Streptococcus agalactiae, Acinetobacter baumanni, $\underline{\text { Shigella }}$

128 flexneri, Salmonella sp.) were subcultured and the respective DNAs were extracted and 129 purified as described by Brenner et al. (1999).

130 Shrimp and haemolymph samples. Thirty juvenile Litopenaeus stylirostris from a

131 grow-out pond (mean weight 8 g.) were used for this study. Twenty were infected with a

$132 \underline{\text { V.penaeicida }}$ AM101 suspension as described by Saulnier et al. (2000). Prior to 133 haemolymph sampling, shrimp were rinsed with sterile seawater. Then, haemolymph was 134 withdrawn from the ventral sinus using a sterile tuberculin syringe and needle, 135 immediately placed on ice and used for DNA extraction. Uninfected shrimp (control), 136 moribund and survivors were sampled, in order to get a large range of $\underline{\mathrm{V} \text {. penaeicida }}$ 137 concentrations in haemolymph specimens.

138 Collection of seawater and sediment pore water samples. Seawater (15 ml) -

139 both from a shrimp grow-out pond and from pumping water - was sampled in a sterile 140 plastic tube. Sediment was sampled in the same pond using a core sampler. Pore water was 141 obtained by low-speed centrifugation of $30 \mathrm{~g}$ of sediment ( $200 \mathrm{x} \mathrm{g}$ for 5 minutes at $4^{\circ} \mathrm{C}$ ).

142 Water and pore water samples (200 or 1,200 $\mu \mathrm{l}$ ) were then pelleted at 20,000 x $g$ for 15 143 minutes at $4^{\circ} \mathrm{C}$. The supernatant was discarded and the pellet immediately chilled on ice 144 and used as the sample for DNA extraction.

145 DNA extraction techniques. DNAs were extracted and purified by three different 146 methods. (i) After lysis and digestion with a $0.5 \%$ sodium dodecyl sulfate (SDS)-0.1 $147 \mathrm{mg} \cdot \mathrm{ml}^{-1}$ proteinase $\mathrm{K}$ solution ( 1 to 3 hours incubation at $56^{\circ} \mathrm{C}$ ), bacterial nucleic acids 
148 were extracted by a phenol-chloroform-isoamyl alcohol (25:24:1, vol/vol/vol) mixture as

149 described by Jackson et al. (1991). The DNA was resuspended in $200 \mu$ l PCR grade water 150 with $50 \mu \mathrm{g} \cdot \mathrm{ml}^{-1} \mathrm{RNase} \mathrm{A}$ (Sigma), incubated $15 \mathrm{~min}$ at $37^{\circ} \mathrm{C}$ and stored at $-80^{\circ} \mathrm{C}$ until use.

151 (ii) Crude shrimp haemolymph $(10 \mu \mathrm{l})$ or bacterial suspensions $(5 \mu \mathrm{l}$ pure culture or serial 152 dilutions) or environmental samples pellets were mixed with $400 \mu \mathrm{l}$ of a $5 \%$ (wt/vol)

153 Chelex 100 suspension (Sigma Chemical Co., St. Louis, Mo.) prepared in $10 \mathrm{mM}$ Tris 154 buffer $\mathrm{pH}$ 8.0. Fifty $\mu \mathrm{l}$ of a $25 \mu \mathrm{g} \cdot \mathrm{ml}^{-1}$ proteinase K solution was then added and samples were incubated for 4 hours at $56^{\circ} \mathrm{C}$, boiled for 15 minutes, placed on ice and stored at $20^{\circ} \mathrm{C}$ until use. (iii) Suspensions (from bacterial culture or serial dilutions, seawater or sediment pore water) and haemolymph samples (from 10 to $200 \mu \mathrm{l}$ ) were used as templates

158 and extracted with the High Pure ${ }^{\mathrm{TM}}$ PCR Template Preparation kit (Roche Diagnostics,

159 New Zealand) as recommended by the manufacturer, following the "whole blood" 160 instructions for this column-based procedure. Eluted DNA was resuspended in $200 \mu \mathrm{l}$ 161 prewarmed elution buffer and stored at $-20^{\circ} \mathrm{C}$ until use.

Primers and real time PCR conditions. Primers VpF (5’-

163 GTGTGAAGTTAATAGCTTCATATC-3’) and VR (5’-

164 CGCATCTGAGTGTCAGTATCT-3') were used from the $\underline{\text { rrs }}$ gene as described by 165 Saulnier et al. (2000). The primers (Proligo Singapore Pte Ltd) amplified a 310-bp product

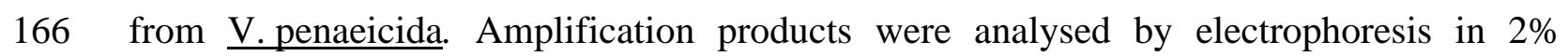
167 NuSieve 3:1 gel agarose (FMC BioProducts, Rockland, ME) with ethidium bromide 168 staining. The LightCycler FastStart DNA Master SYBR Green I kit (Roche Diagnostics, 169 New Zealand) was used as the basis for the reaction mixture, using a $20 \mu \mathrm{l}$ volume in each 170 reaction capillary. The reaction master mix included a dNTP mix (with dUTP instead of 171 dTTP), SYBR Green I dye, FastStart Taq DNA polymerase (a hot-start enzyme), 4 mM $172 \mathrm{MgCl}_{2}$ and $0.5 \mu \mathrm{M}$ of each primer. After distributing $18 \mu \mathrm{l}$ aliquots of the master mix 
173 among the capillaries, $2 \mu \mathrm{l}$ of the DNA was added before the capillaries were capped, 174 centrifuged and placed in the LightCycler sample carousel. A negative control with PCR175 grade water rather than template DNA was always used with the samples. Aerosol-barrier

176 pipette tips were used throughout the procedure. The PCR conditions were optimised 177 regarding the annealing temperature, $\mathrm{MgCl}_{2}$ concentration and sample DNA volume. 178 Amplification conditions involved a pre-incubation at $95^{\circ} \mathrm{C}$ for $10 \mathrm{~min}$ (FastStart Taq 179 DNA polymerase activation) followed by amplification of the target DNA for 50 cycles $180\left(95^{\circ} \mathrm{C}\right.$ for $8 \mathrm{sec}, 60^{\circ} \mathrm{C}$ for $5 \mathrm{sec}$ and $72^{\circ} \mathrm{C}$ for $\left.13 \mathrm{sec}\right)$ with a transition rate of $20^{\circ} \mathrm{C} / \mathrm{sec}$. Melting curve analysis was performed at a linear temperature transition rate of $0.1^{\circ} \mathrm{C} / \mathrm{sec}$

182 from $65^{\circ} \mathrm{C}$ to $95^{\circ} \mathrm{C}$ with continuous fluorescence acquisition. This step was followed by a 183 cooling step at $40^{\circ} \mathrm{C}$ for 30 sec. The first derivative of the initial melting curve (-dF/dT) was automatically plotted against temperature for improved determination of the melting temperature (Tm). All experiments were repeated at least twice for reproducibility.

\section{RESULTS}

Specificity of detection. The specificity of our real-time assay was evaluated by testing the members of the genus Vibrio, mentioned above, which covered a broad range of Vibrio species and a range of other species covering phylogenetically related species, and representatives of species from other branches. Our real-time PCR assay only amplified the

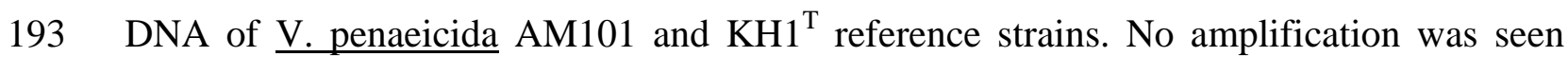
194 with any of the non- $\underline{\mathrm{V}}$. penaeicida or other non- $\underline{\text { Vibrio }}$ bacterial species tested in this study. 195 All PCR products of amplified samples were visualized by gel electrophoresis (5 $\mu \mathrm{l}$ of each PCR product on a 1.5\% agarose gel containing ethidium bromide) and showed a unique 310-bp band (Fig. 1). Additionally, fluorescence melting curve analysis showed a 
specific discriminant melting temperature. Indeed, a mean melting temperature of $87.1^{\circ} \mathrm{C}$

199 was obtained for both $\underline{\mathrm{V} \text {. penaeicida }}$ reference strains (Fig. 2). All negative samples showed no amplification caused by primer-dimer formation (Fig. 2).

202 V.penaeicida by real time PCR. In order to assess the quality of the extraction process, 203 comparative amplifications were run between DNAs extracted from 10-fold dilutions of a

$204 \underline{V}$. penaeicida culture. The relative concentration of Vibrio DNA recovered from samples by the different extraction methods was measured by determining the PCR cycle at which amplicon specific fluorescence became detectable by crossing a noise band positioned above background values of fluorescence using the LightCycler software (Read, 2001).

208 Representative results with the three extraction methods over a 6-log-unit range of 209 concentration (1 to $10^{5} \mathrm{CFU} \cdot \mathrm{mL}^{-1}$ ) are shown in Figure 3. The whole extraction and amplification using each method where repeated five times. Briefly, with Chelex

211 preparations or DNAs extracted with High Pure ${ }^{\mathrm{TM}}$ PCR Template Preparation Kit,

212 comparable amplification results were obtained. The detection of $\underline{\mathrm{V} \text {. penaeicida from pure }}$

213 cultures, using the column-based High Pure ${ }^{\mathrm{TM}}$ kit, was possible over a 8-log-unit linear

214 range of concentration ( 1 to $10^{7} \mathrm{CFU} \cdot \mathrm{mL}^{-1}$ ) and over a 6-log-unit linear range (1 to $10^{5}$

215 CFU.mL ${ }^{-1}$ ) using Chelex preparations . The detection limit appeared to be around one 216 single cell per reaction capillary. The correlation between quantitative results

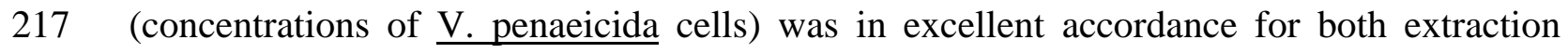
218 procedures (Chelex, silica matrix), as illustrated in Fig. 3B and 3C, with respective $r$ values 219 of 0.9955 and 0.9854 . The variation in the extraction (both previous methods) and amplification efficiency for 5 recorded runs (with 5 replicates for each Vibrio dilution) was

$221<2 \%$ relative standard deviation. At the opposite, when working with phenol-chlororform222 isoamyl alcohol extracts, large differences were observed for all replicates of a same 
223 dilution (Fig. 3A). Indeed, compared to Chelex and High Pure ${ }^{\mathrm{TM}}$ PCR Template

224 Preparation Kit, for each dilution tested, the mean difference was greater and not acceptable. Therefore, field samples (either haemolymph, pond or bay water, sediment pore water) were only extracted with either the Chelex or High Pure ${ }^{\mathrm{TM}}$ techniques.

Real time PCR with field samples. Samples from various compartments of the shrimp farm ecosystem were tested identically. It should be noted that we experienced difficulty obtaining "naturally” infected shrimps, so our panel only contained a limited number of experimentally infected shrimps in laboratory conditions. For shrimp haemolymph specimens, best results were obtained when the initial sample volume was $10 \mu \mathrm{L}$, when compared to 50, 100 or $200 \mu \mathrm{L}$. Indeed, from $100 \mu \mathrm{L}$ on, haemolymph clotting appeared to be the major factor inducing low extraction yields. Our samples demonstrated various

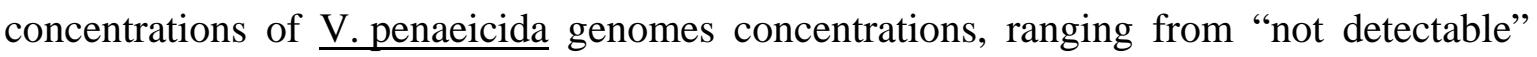
(apparently healthy shrimp and shrimp surviving 5 days after experimental infection) to 8.4x $10^{4} . \mu L^{-1}$ (moribund shrimp, after experimental infection). Still, some apparently healthy shrimp and shrimp surviving experimental infection displayed concentrations of up

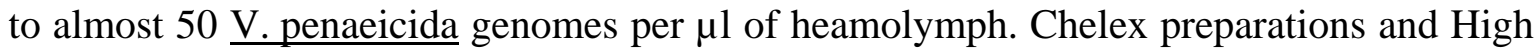

241 Pure $^{\mathrm{TM}}$ PCR Template Preparation Kit extracts gave similar results as $\underline{\text { V.penaeicida }}$

242 genomes per initial sample $\mu \mathrm{L}$, the largest ratio between the two techniques being 2.1 in a 243 moribund shrimp sample.

244 For water samples, the Chelex ${ }^{\mathrm{TM}}$ preparations frequently gave no amplifications. In contrast, High Pure ${ }^{\mathrm{TM}}$ PCR Template Preparation Kit extracts gave positive amplifications;

246 best results being obtained when extracting from the pellet from a $200 \mu \mathrm{L}$ volume of initial

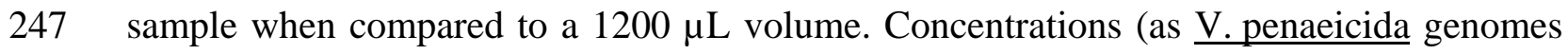


per initial sample $\mathrm{mL}$ ) ranging from "not detectable" to 660 were found in pumping water,

249 from 330 to 1830 in shrimp pond water and from 52 to 1210 in sediment pore water.

250

\section{Discussion:}

Detailed mechanisms of shrimp vibriosis have until now only received poor research attention, so that little knowledge has been gained on this pathology. This has been mainly due to the fact that the use of antibiotic feeds could often get rid of the disease. Nevertheless, the massive use of antibiotics has led to the selection of antibioticresistant bacterial strains (Brown, 1989; Karunasagar et al., 1994) and highlighted the inefficiency of such an approach. Furthermore some producing countries, including New Caledonia, have totally banned the use of antibiotics in grow-out ponds (Andrier, 2004) and most importing countries have drastically decreased tolerance on antimicrobial residues. Therefore, research programs aiming at gaining a global understanding of shrimp vibriosis are now being developed (Harache and Herbland, 2004). These findings emphasize the need to set up a sensitive and reliable method that can detect and quantify

263 pathogenic $\underline{\mathrm{V} \text {. penaeicida }}$ both in shrimp and their surrounding ecosystem. The polymerase 264 chain reaction (PCR) has the potential to make a dramatic impact in diagnosing vibriosis, 265 allowing the detection of many Vibrio species whatever their culturability. Although $\underline{\text { rrs }}$

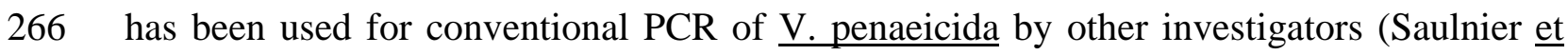
267 al., 2000 ; Goarant et al., 2004), the method is time-consuming and does not provide 268 quantitative results of $\underline{V}$. penaeicida infectious levels in shrimp and environmental 269 samples. Therefore, it was necessary to transfer this protocol to a real-time PCR platform. 270 This method has already been used to study the major shrimp viral pathogens (Dhar et al., 2712001 ; Dhar et al., 2002 ; Durand et al., 2003 ; Tang et al., 2004) and was successfully 
applied to quantification of human-pathogenic Vibrio, and in some cases in marine invertebrates (Campbell and Wright, 2003).

The detection of microbial pathogens in various biological samples by real-time PCR with SYBR Green I dye has been shown to be rapid, reliable, sensitive and costeffective. As a first step, we evaluated and established a simple, fast and effective DNA

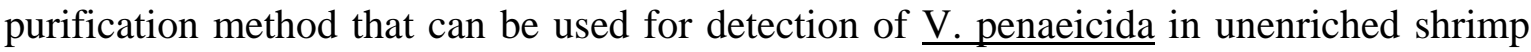
haemolymph and water samples; without compromising the quality of DNA and real-time PCR efficiency. To this end, the yield from an extraction method should not be influenced by the initial amount of target nucleic acid in the sample. PCR is prone to inhibition (Tsai and Olson, 1992 ; Wilson, 1997 ; Frostegard et al., 1999 ; Watson and Blackwell, 2000 ;

282 Dumètre and Dardé, 2003) and marine environmental samples are known to contain substances that can potentially interfere with the amplification process (Audemard et al., 2004 ; Goarant et al., 2004).Therefore an adequate extraction protocol must be used for nucleic acids extraction and purification. In our evaluation, the classical phenolchloroform-isoamyl alcohol extraction process did not satisfy these requirements. Indeed,

287 the pipetting of the aqueous supernatant could not be efficiently completed. We observed a 288 decreased sensitivity due to the loss of template DNA during multiple processing steps and 289 the amount of proteins in samples may influence the recovery of nucleic acids. Finally, with such results it was impossible to build a robust standard curve and this method was definitively abandoned. Conversely, the Chelex preparation technique showed that there 292 was a strong correlation between the initial amount of target DNA and real-time PCR Cp 293 values as expected. Successive increases in Cp values with the expected melting temperature $\left(87.1^{\circ} \mathrm{C}\right)$ were observed as the concentration of template DNA in the samples decreased. The Chelex protocol allows a single-tube technique without lost of nucleic acids, however, all chemical compounds (including PCR-inhibiting substances) present in 
297 the initial sample are collected with nucleic acids. Using a commercial extraction and 298 purification kit (High Pure ${ }^{\mathrm{TM}}$ PCR Template Preparation kit) we could get positive 299 amplifications from bay seawater, shrimp pond water and even sediment pore water 300 samples. All of these samples failed to amplify when using Chelex DNA preparations. The

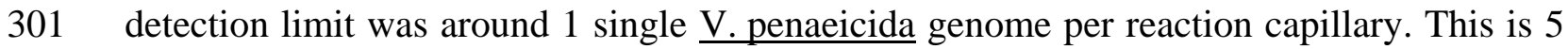
302 times lower than classical PCR with the same primers which allowed detection of 20 303 genomes per reaction (in a $10 \mu \mathrm{L}$ extract sample) as described by Saulnier et al., (2000). 304 This very low detection limit is quite common using real time PCR especially when 305 dealing with multi-copy gene targets, which is the case for $\underline{\operatorname{rrs}}$ (Moreno et al., 2002). Interestingly, all $\underline{\mathrm{V} \text {.penaeicida }}$ strains isolated to date in New Caledonia 307 demonstrated high pathogenicity when tested by experimental infection in a shrimp model 308 (Goarant et al., unpublished data), which is quite different from other aquaculture 309 pathogenic Vibrio spp. (Liu et al., 1996 ; Zhang et al., 2001 ; Toranzo et al., 1983).

310 Therefore we can assume that the quantification of $\underline{\mathrm{V}}$. penaeicida in shrimp and marine 311 samples actually corresponds to the quantification of pathogenic $\mathrm{V}$. penaeicida cells. While 312 studying our samples, we were also able to confirm these previous results. Regarding the 313 environmental samples, we confirmed that $\mathrm{V}$. penaeicida is frequently present in water 314 pumped from the bays, which might therefore be the infectious origin for the grow-out

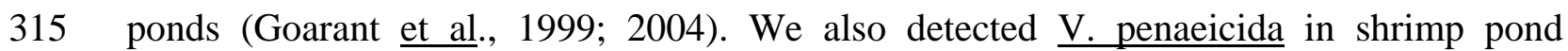
316 sediment pore water, confirming that inhibitors can frequently alter the detection of 317 pathogenic Vibrio when using inappropriate nucleic acids extraction method such as 318 Chelex technique (Goarant et al., 2004). Additionally, we confirmed the presence of 319 V. penaeicida in apparently healthy shrimp (Goarant et al., 2004). In this study, we successfully developed a real-time PCR assay with SYBR Green I

321 dye for the quantification of bacterial pathogen $\underline{\mathrm{V} \text {. penaeicida }}$ in both shrimp and 
322 environmental samples. This technology enables PCR to be performed with greatly

323 reduced carry-over contamination risk and with minimal hands-on time. Although melting

324 curve analysis with SYBR Green is sometimes considered less specific compared to the

325 use of fluorescent probes, the need of more expensive probes is not always necessary when

326 conditions of amplification have been correctly optimized (especially primer sequences and

327 concentrations). The specific product melting peaks with no primer-dimer or other non-

328 specific product signal provided evidence that our assay is specific. Moreover, our

329 turnaround time was considerably faster with the new real-time PCR assay. The complete

330 process - including sample processing, extraction of DNA and real-time PCR amplification

331 with quantification - was achieved within 4 hours, making it a single-day assay and a

332 prospective decision tool for shrimp growers, depending on the quantification results. As a

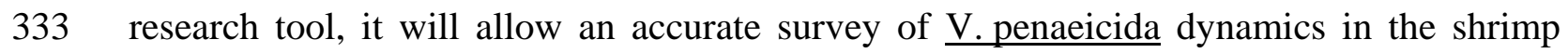

334 farm ecosystem, including a possible seasonal pattern in the seawater from the bays - water

335 temperature being a major trigger in Syndrome 93 occurrence (Goarant et al., 2000). It can

336 also be used to study the dynamics of the pathogen in experimentally infected shrimp, as

337 shown with our preliminary data. In the enzootic context of New Caledonia, it will also be

338 a tool to study the effect on healthy carriage of various parameters, either intrinsic like

339 molt stage, developmental stage (Goarant et al., 1998), juvenile age, weight or extrinsic

340 (water temperature, dissolved oxygen, ammonia concentration, feed quality or feed

341 additives, probiotics).

343 Acknowledgments

344 This work was partly supported by grants from the South and North Provinces of New

345 Caledonia, IFREMER and the French Ministry of Research. Thanks are due to Dominique 
346 Ansquer and Sophie De Decker for technical help during experimental infection of shrimp

347 and DNA extraction. The authors are indebted to J.F. Mackay for editorial contributions. 
349 Andrier, P., 2004. Une vision globale de l'aquaculture de crevettes et de son marché. In : Styli 2003. Trente ans de crevetticulture en Nouvelle-Calédonie. Nouméa-Koné, 2-6 juin 2003. Éd. Ifremer, Actes Colloq., 38. pp. 18-22. (in french with english abstract).

352

Audemard, C., Reece, K.S., Burreson E.M., 2004. Real-Time PCR for detection and quantification of the protistan parasite Perkinsus marinus in environmental waters. Appl. Environ. Microbiol. 70, 6611-6618.

Baffone, W., Citterio, B., Vittoria, E., Casaroli, A., Campana, R., Falzano, L., Donelli, G., 2003. Retention of virulence in viable but non-culturable Vibrio spp. Int. J. Food Microbiol. 89, 31-39.

Blackstone GM, Nordstrom JL, Vickery MC, Bowen MD, Meyer RF, DePaola A., 2003. Detection of pathogenic Vibrio parahaemolyticus in oyster enrichments by real time PCR. J. Microbiol. Methods. 53, 149-155.

Brenner, D.J., Kaufmann, A.F., Sulzer, K.R., Steigerwalt, A.G., Rogers, F.C., Weyant, R.S., 1999. Further determination of DNA relatedness between serogroups and serovars in the family Leptospiraceae with a proposal for Leptospira alexanderi sp. nov. and four new Leptospira genomospecies. Int. J. Syst. Bacteriol. 49, 839-858.

Brock, J. A., LeaMaster, B., 1992. A look at the principal bacterial, fungal and parasitic diseases of farmed shrimp. In J. Wyban (Ed.), Proceedings of the Special Session on Shrimp Farming. World Aquaculture Society, Baton Rouge, La. pp. 212-226.

Brown, J.H., 1989. Antibiotics: their use and abuse in aquaculture. World Aquaculture 20, 34-49.

Campbell, M.S., Wright, A.C., 2003. Real-time PCR analysis of Vibrio vulnificus from oysters. Appl. Environ. Microbiol. 69, 7137-7144. 
Costa, R., Mermoud, I., Koblavi, S., Morlet, B., Haffner, P., Berthe, F., Le Groumellec, M., Grimont, P., 1998. Isolation and characterization of bacteria associated with a

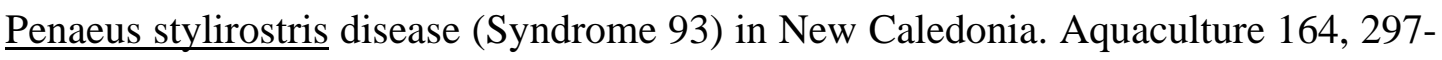
309.

Dhar, A.K., Roux, M.M., Klimpel, K.R., 2001. Detection and quantification of infectious hypodermal and hematopoietic necrosis virus and white spot virus in shrimp using real-time quantitative PCR and SYBR green chemistry. J. Clin. Microbiol. 39, 28352845.

Dhar, A.K., Roux, M.M., Klimpel, K.R., 2002. Quantitative assay for measuring the Taura syndrome virus and yellow head virus load in shrimp by real-time RT-PCR using SYBR Green chemistry. J. Virol. Methods 104, 69-82.

Dumètre, A., Dardé, M.L., 2003. How to detect Toxoplasma gondii oocysts in environmental samples? FEMS Microbiol. Rev. 27:651-661.

Durand, S.V., Redman, R.M., Mohney, L.L., Tang-Nelson, K., Bonami, J.R., Lightner, D.V., 2003. Qualitative and quantitative studies on the relative virus load of tails and heads of shrimp acutely infected with WSSV. Aquaculture 216, 9-18.

Fischer-Le-Saux, M., Hervio-Heath, D., Loaec, S., Colwell, R.R., Pommepuy, M., 2002. Detection of cytotoxin-hemolysin mRNA in nonculturable populations of environmental and clinical Vibrio vulnificus strains in artificial seawater. Appl. Environ. Microbiol. 68, 5641-5646.

Frostegard, A., Courtois, S., Ramisse, V., Clerc, S., Bernillon, D., Le Gall, F., Jeannin, P., Nesme, X., Simonet, P., 1999. Quantification of bias to the extraction of DNA directly from soils. Appl. Environ. Microbiol. 65, 5409-5420. 
Goarant, C., Régnier, F., Brizard, R., Marteau, A.L., 1998. Acquisition of susceptibility to

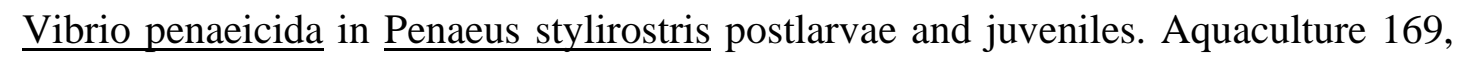
291-296.

Goarant, C., Mérien, F., Berthe, F., Mermoud, I., Pérolat, P., 1999. Arbitrarily primed PCR to type Vibrio spp. pathogenic for shrimp. Appl. Environ. Microbiol. 65, 1145-1151.

Goarant, C., Herlin, J., Brizard, R., Marteau, A.L., Martin, C., Martin, B., 2000. Toxic 401 factors of Vibrio strains pathogenic to shrimp. Dis. Aquat. Org. 40, 101-107.

Goarant, C., Mermoud, I., Costa, R., Haffner, P., Boglio E., 1996. Study of episodes of 403 mortality observed in reared Penaeus stylirostris since 1993 in New Caledonia: I. Biotechnical impact and gross signs in diseased prawns. World Aquaculture Society editor. Book of abstracts World Aquaculture Society annual conference. pp. 139-140.

Goarant, C., Herlin, J., Ansquer, D., Brizard, R., Marteau, A.L., 2004. Vibrio penaeicida 407 and Syndrome 93 in New Caledonian prawn farming : review and perspectives. In : Styli 2003. Trente ans de crevetticulture en Nouvelle-Calédonie. Nouméa-Koné, 2-6

Harache, Y., Herbland, A., 2004. Le programme DESANS (Défi Santé Stylirostris) : une démarche comparable au Défi MOREST appliquée à la filière crevette Calédonienne. In : Styli 2003. Trente ans de crevetticulture en Nouvelle-Calédonie. Nouméa-Koné, 2-6 juin 2003. Éd. Ifremer, Actes Colloq., 38. pp 31-38 (in french with english abstract).

Huq, A., Colwell, R.R., 1995. A microbiological paradox: viable but nonculturable bacteria with special reference to Vibrio cholerae. J. Food Protect. 59, 96-101. 
418 Jackson, D.P., Hayden, J.D., Quirke, P., 1991. Extraction of nucleic acid from fresh and 419 archival material. In: McPherson MJ, Quirke P, Taylor GR (eds) PCR: a practical 420 approach. IRL Press at Oxford University Press, Oxford, pp 29-49.

421 Karunasagar, I., Pai, R, Malathi, G.R., Karunasagar, I., 1994. Mass mortality of Penaeus 422 monodon larvae due to antibiotic-resistant Vibrio harveyi infection. Aquaculture 128, $423 \quad 203-209$.

424 Lightner, D.V., 1988. Vibrio disease of penaeid shrimp. In C. J. Sindermann and D. V. 425 Lightner (ed.), Disease diagnosis and control in North American marine aquaculture. $426 \quad$ Elsevier, Amsterdam, The Netherlands. pp. 42-47.

427 Lightner, D.V., Lewis, D.H., 1975. A septicemic bacterial disease syndrome of penaeid 428 shrimp. Mar. Fish. Rev. 37, 25-28.

429 Liu, P.C., Lee, K.K., Chen, S.N. 1996. Pathogenicity of different isolates of Vibrio harveyi 430 in Tiger Prawn, Penaeus monodon. Lett. Appl. Microbiol. 22, 413-416.

431 Mermoud, I., Costa, R., Ferré, O., Goarant, C., Haffner, P., 1998. Syndrome 93 in New 432 Caledonian outdoor rearing ponds of Penaeus stylirostris: history and description of 433 the three major outbreaks. Aquaculture 164, 323-335.

434

435

436

437

438

439

Mohney, L.L., Lightner, D.V., 1994. An epizootic of vibriosis in Ecuadorian pond-reared Penaeus vannamei Boone (Crustacea: Decapoda). J. World Aquacult. Soc. 25, 116125.

Moreno, C., Romero, J., Espejo, R.T., 2002. Polymorphism in repeated 16S rRNA genes is a common property of type strains and environmental isolates of the genus Vibrio. Microbiol.-SGM 148, 1233-1239. 
440 Panicker, G., Myers, M.L. Bej, A.K., 2004. Rapid detection of Vibrio vulnificus in shellfish and gulf of Mexico water by real-time PCR. Appl. Environ. Microbiol. 70, 498-507.

Read, S. J., 2001. Recovery efficiencies of nucleic acid extraction kits as measured by quantitative LightCycler PCR. J. Clin. Pathol. : Mol. Pathol. 54, 86-90.

Rosenberg, E, Ben-Haim, Y., 2002. Microbial diseases of corals and global warming. Environ. Microbiol. 4, 318-326.

Saulnier, D., Avarre, J-C, Le Moullac, G., Ansquer, D., Levy, P., Vonau, V., 2000. Rapid and sensitive PCR detection of Vibrio penaeicida, the putative etiological agent of Syndrome 93 in New Caledonia. Dis. Aquat. Org. 40, 109-115.

Takahashi, Y., Shimomaya, Y., Momomaya, K., 1985. Pathogenicity and characteristics of 451

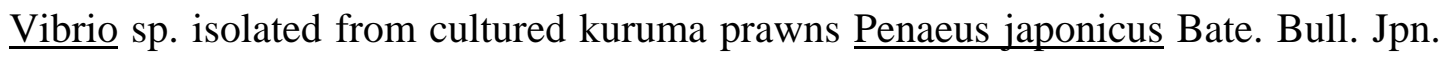

Tang, K.F.J., Wang, J., Lightner, D.V., 2004. Quantitation of Taura syndrome virus by 454 real-time RT-PCR with a TaqMan assay. J. Virol. Methods 115:109-114.

Toranzo, A.E., Barja, J.L., Potter, J.L., Colwell, R.R., Hetrick, F.M., Crosa, J.H., 1983. Molecular factors associated with virulence of marine Vibrios isolated from striped bass in Chesapeake Bay. Infect. Immun. 39, 1220-1227.

Tsai, Y. L., Olson, B. H., 1992. Rapid method for separation of bacterial DNA from humic substances in sediments for polymerase chain reaction. Appl. Environ. Microbiol. 58,

Watson, R. J., Blackwell, B., 2000. Purification and characterization of a common soil 462 component which inhibits the polymerase chain reaction. Can. J. Microbiol. 46, 633642. 
464 Weppe, M., Bonami, J.R., Lightner, D.V., AQUACOP. 1992. Demostración de la altas

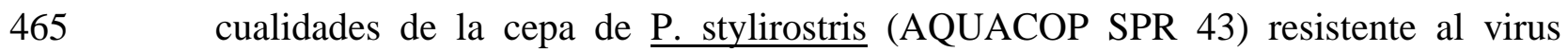
466 IHHN. in Memorias I Congreso Ecuatoriano de acuicultura, Ed. : Escuela Superior 467 Politécnica del Litoral, 1993 pp. 229-232 (in spanish).

468 Wilson, I.G., 1997. Inhibition and facilitation of nucleic acid amplification. Appl. Environ. $469 \quad$ Microbiol. 63, 3741-3751.

470 Zhang, X.H., Meaden, P.G., Austin, B., 2001. Duplication of hemolysin genes in a virulent 471 isolate of Vibrio harveyi. Appl. Environ. Microbiol. 67, 3161-3167.

472 
472 Figure 1. Example of real-time PCR amplification of strains from various Vibrio species

473 and bacterial strains other than members of the genus Vibrio demonstrated by agarose gel

474 electrophoresis after ethidium bromide staining. Two ng of template DNA was used in the

475 PCR (50 cycles with primers VpF and VR). Lanes : (1) V. penaeicida AM101, (2)

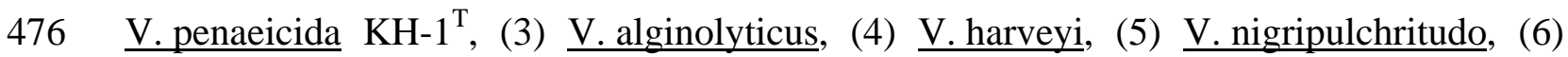

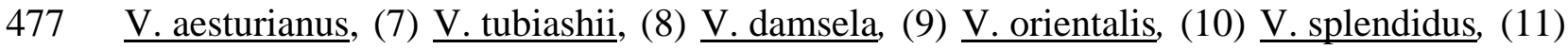

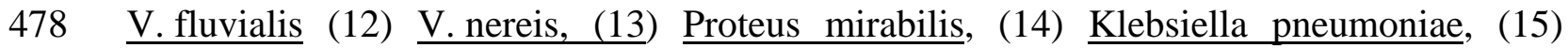

479 Escherichia coli, (16) Staphylococcus aureus, (17) Streptococcus agalactiae, (18)

480 Acinetobacter baumanni, (19) Shigella flexneri, (20) Salmonella sp. (PM) Step Ladder 50

481 bp (Sigma Chemical Co. St. Louis, Mo.) used as a DNA size marker (in base pairs).

482

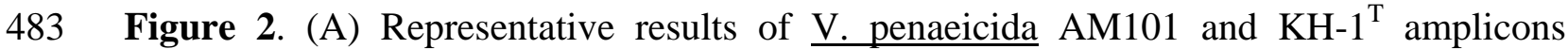
484 detection in channel F1. The fluorescence values versus cycle number are displayed. Two 485 ng of purified DNA (Brenner et al., 1999) were used as positive control. As a negative 486 control (NC), the template DNA was replaced with PCR-grade water. (B) Melting curve analysis after real-time amplification with VpF and VR primers and SYBR Green dye in the LightCycler.

489

490

Figure 3. Quantitative results obtained for Vibrio penaeicida after extraction by phenolchlororform-isoamyl alcohol (A), Chelex (B) and Roche High pure PCR preparation kit

492 (C). Cp (crossing point) values versus ibrio density $\left(\log _{10}\right.$ CFU.mL $\left.{ }^{-1}\right)$ are displayed. Five 493 replicates were tested with the different dilutions of Vibrio. The triangles (open symbols) 494 represent the mean difference between the quantitative results (squares, closed symbols). 495 Error bars indicate the standard deviation. The solid line represents the correlation between 496 the Cp values and Vibrio concentrations. 
497 Figure 1

498

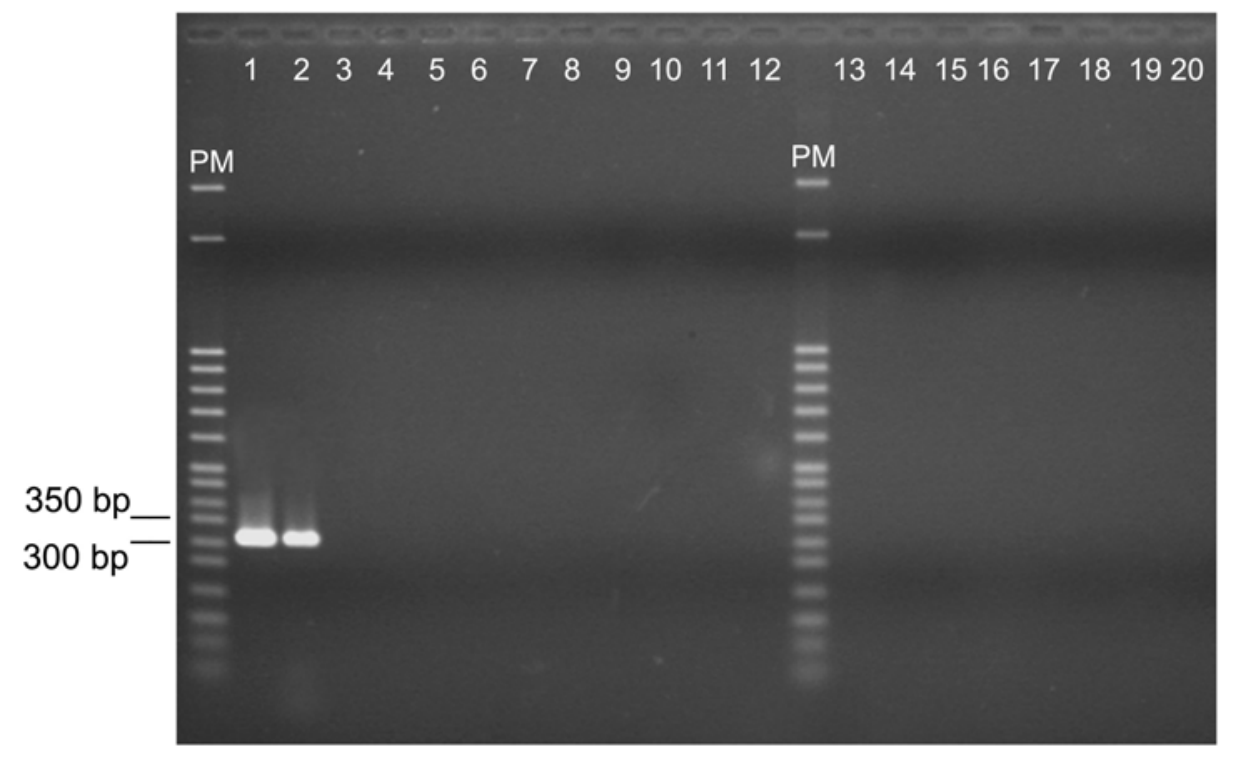

499

500

501 
Figure 2

502
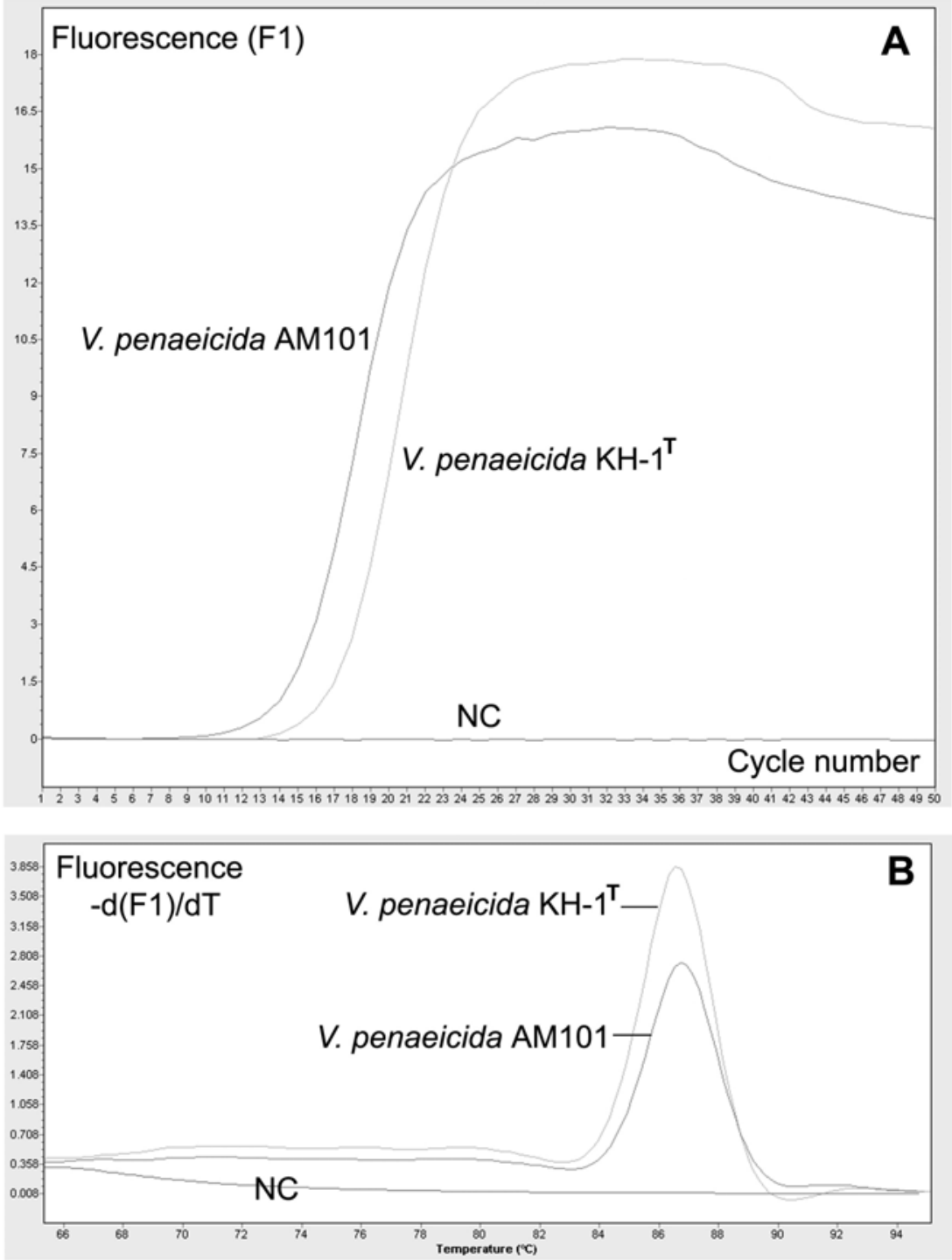
Figure 3

505

A

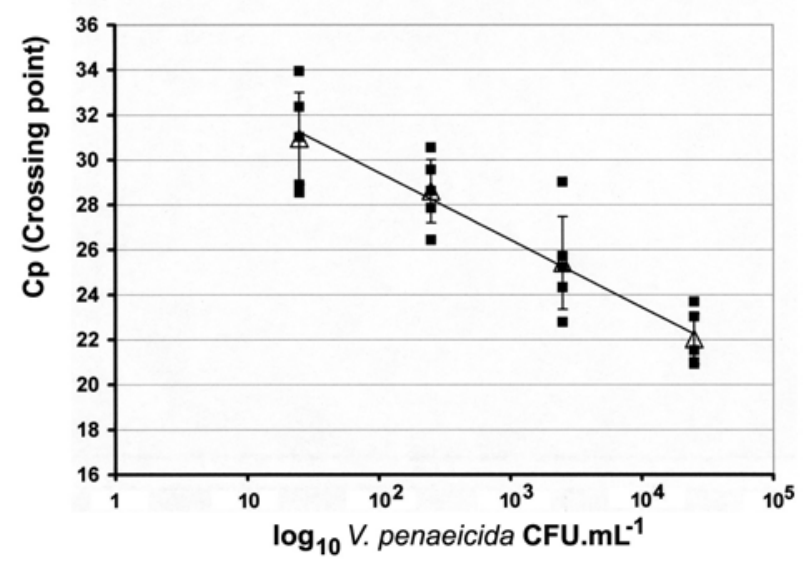

B

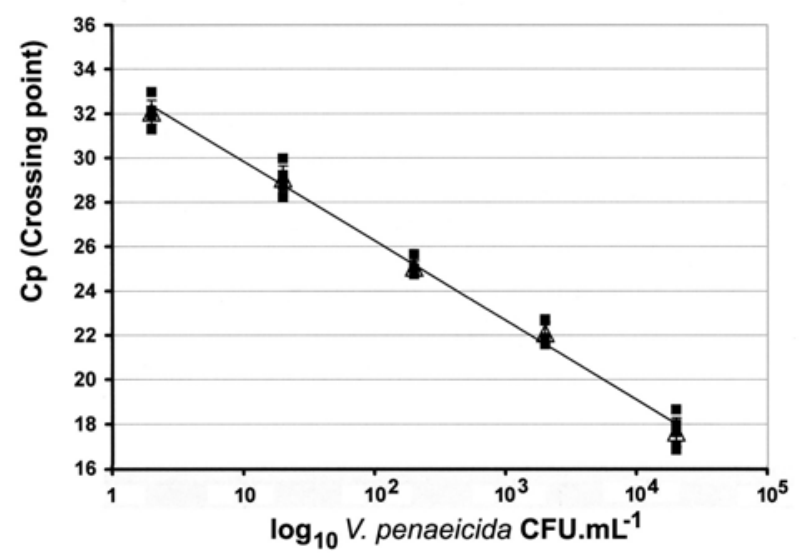

C

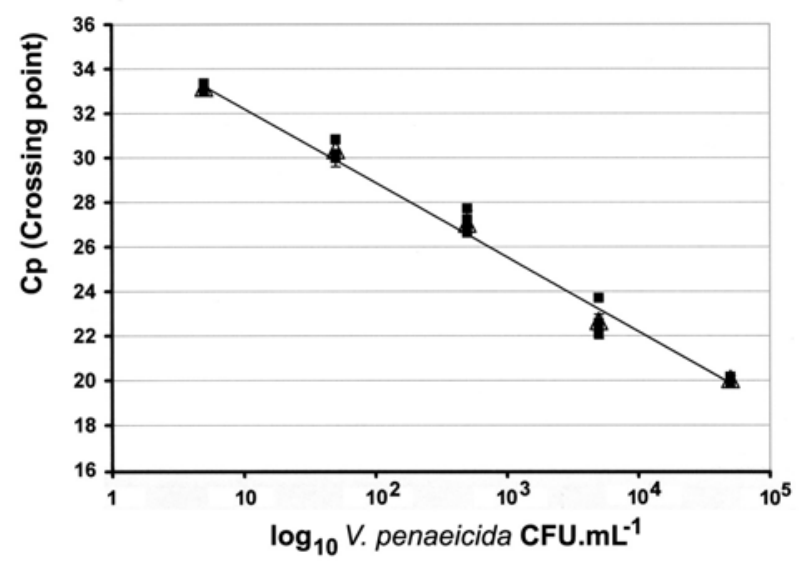

